Article

\title{
A Methodology to Support Decision-Making Towards an Energy-Efficiency Conscious Design of Residential Building Envelope Retrofitting
}

\section{Thaleia Konstantinou}

Delft University of Technology, Julianalaan 134, 2628BL Delft, The Netherlands;

E-Mail: t.konstantinou@tudelft.nl; Tel.: +31-0-648272643

Academic Editor: David Dernie

Received: 24 September 2015 / Accepted: 10 November 2015 / Published: 17 November 2015

\begin{abstract}
Over the next decade investment in building energy savings needs to increase, together with the rate and depth of renovations, to achieve the required reduction in buildingrelated $\mathrm{CO}_{2}$ emissions. Although the need to improve residential buildings has been identified, guidelines come as general suggestions that fail to address the diversity of each project and give specific answers on how these requirements can be implemented in the design. During early design phases, architects are in search of a design direction to make informed decisions, particularly with regard to the building envelope, which mostly regulates energy demand. To result in an energy-efficient residential stock, this paper proposes a methodology to support refurbishment strategies design. The methodology, called "façade refurbishment toolbox (FRT) approach”, is based on compiling and quantifying retrofitting measures that can be also seen as "tools" used to upgrade the building's energy performance. The result of the proposed methodology enables designers to make informed decisions that lead to energy and sustainability conscious designs, without dictating an optimal solution, from the energy point of view alone. Its applicability is validated through interviews with refurbishment stakeholders.
\end{abstract}

Keywords: refurbishment; residential energy upgrade; design process

\section{Introduction}

Over the next decade investment in building energy savings needs to increase, together with the rate and depth of renovations [1], in order to meet the requirement for building-related $\mathrm{CO}_{2}$ emissions 
reduction that reaches up to $90 \%$ by 2050 [2]. The domestic sector has the potential to make a significant contribution [3], as households consume approximately $1 / 4$ of the final energy use in the European Union [4] and, thus, offer larger energy saving possibilities than other sectors, along with the necessary higher investment [5]. Moreover, residential buildings account for 2/3 of building floor area, while the condition and efficiency of a large part of the residential stock still needs attention.

The importance of the building sector's has led to the European directive on the energy performance of buildings (EPBD), which requires an energy performance certificate when buildings are constructed, sold, or rented out. In order to achieve significant reductions in $\mathrm{CO}_{2}$ emissions, the directive was updated in 2010, requiring new buildings to be low- or zero-energy buildings [6]. However, a greater challenge that must be faced, in order to tackle the energy demand of the building sector and to effectively implement the energy performance building directive (EPBD), is the proper refurbishment of existing buildings. More than $70 \%$ of the 2050 building stock is already built, considering the current rates of construction, demolition, and renovation across Europe [7]. Moreover, the analysis of the European Commission's roadmap projects that, over the next decade, investments in energy-saving building components and equipment need to be increased by up to $€ 200$ billion [2], together with a substantial increase in the rate and depth of renovations [1]. An increase in building energy performance could constitute an important instrument in the efforts toward alleviating the EU's energy import dependency and reach national and international targets for the reduction of carbon dioxide emissions. Not only does it provide huge potentials for energy savings, but it is also economically and socially relevant. Technical problems, operational costs, and internal conditions can be improved, resulting in more favorable living and working conditions, as well as increased property value.

Despite the acknowledged need to upgrade existing residential buildings, guidelines come as general suggestions that fail to address the diversity of each project and give specific answers on how these requirements can be implemented in the design. Achieving energy savings in buildings is a complex issue and decision-making process defines the final result. Researchers, such as Ma et al. [8], Ferreira et al. [9], and Cooper et al. [10], have identified different phases in the design and execution of refurbishment strategies. Five phases are typically encountered: pre-design, concept design, final design, execution and, finally, the refurbished building.

Requirements for energy performance are normally already set in the pre-design phase. The assessment, however, often happens in Phase Three, when the different options have been investigated and the design is being finalized. More than $80 \%$ of the building performance, in terms of energy savings, generation, and cost, is set during the design phase [11]. At this stage, the architects are in a constant search for a design direction to make informed decisions [12]. An evaluation is needed to support decision-making when various scenarios are discussed. To determine the energy performance of a building, architects typically rely on the input of outside experts, which can slow down the design process [13]. Estimating the refurbished building performance is essential during the decision-making for refurbishment and there are already methodologies and tools have been developed to make this estimation. However, only $1 \%$ of these tools is targeting architects during the early design phases, and architects are reluctant to integrate them into the design process, considering these tools non-user-friendly. Decisions taken during this stage can determine the success or failure of the design [12]. Analysis of some tools has identified as a problem the level of performance feedback in relation to a specific design phase [13], as 
they are often used for post-design evaluation [14]. There is a need for decision support tools that integrate energy simulation into early designs in architectural practice.

To address these issues, with the ultimate goal of bringing about a better performing residential stock, this paper proposes a methodology to support refurbishment strategies design. The methodology, called the "façade refurbishment toolbox (FRT) approach", is based on compiling and quantifying retrofitting measures that can be also seen as “tools” used to upgrade the building's energy performance.

Subsequently, the effect of each measure is quantified. The building performance is assessed in terms of energy demand. Finally, the paper demonstrates how the approach can be further implemented. After each building is associated with the pre-calculated models, it is possible to provide data on potential energy savings. This information differs in different buildings and, combined with individual requirements of the project, lead to different solutions. The decision-making process is supported by the FRT database, as the different options were available and their effect on the heating energy demand was indicated. However, during the design process of the refurbishment strategy, it was proven that the energy reduction cannot always be the only decisive factor. The key points identified through this process were considerations regarding the existing building condition, the possibility to change the appearance, the building program, the energy savings, the level of investment, and the options for energy generation. This process and key considerations are explained in the design of two case study buildings, resulting in a roadmap to the FRT use.

\section{Methodology}

The methodology used to develop the façade refurbishment toolbox approach includes organizing and calculating information about component retrofitting measures. Thus, it consists of different steps, as explained below:

- Systematically organize different refurbishment measures

- Quantify retrofitting measures

- Create a roadmap to use the data during the design, based on a case-study refurbishment strategies design.

- $\quad$ Check the approach's usability and combine all findings in the final database.

The developed approach is also referred to as "toolbox approach". The different retrofitting measures are the "tools" that constitute the refurbishment strategy. In this sense, the organization of the different measures compiles a "façade refurbishment toolbox", from which the refurbishment design selects the tools to use to retrofit the building envelope.

\subsection{Systematically Organize Different Refurbishment Measures: Toolbox Compilation}

To enable the evaluation of the different measures, the first step of the approach is to systematically compile and organize them, according to the building envelope component they address. When it comes to integrated refurbishment, all the key aspects of the building envelope need to be considered and included in the refurbishment measures. The key components, which exist in the thermal envelope, are where heat losses occur. Depending on the design and function of the occupied spaces, these are the exterior wall, windows, balcony ceiling or ground floor, roof or top floor ceiling, balcony slab, etc. 
Building services should not be neglected, as they can be connected to the envelope as well, for example in the case of distribution systems or solar panels.

\subsection{Quantify Toolbox Options}

After defining the different possible retrofitting measures, it is essential to assess how the measures contribute to the energy efficiency upgrade. The quantification of the energy efficiency upgrade is expressed as the reduction in energy demand prior to and after their application. For the comparison to be possible, the energy demand of existing buildings is simulated first. As the approach aims at supporting future refurbishment projects and it is not limited to specific case studies, the options calculated need to cover a wide range of buildings. Following the assessment of existing buildings' performance, each refurbishment option is individually simulated. Every option is simulated separately, by changing only one component in the model of the existing building. To quantify this effect, dynamic simulation is used. The software used for the thermal simulation is DesignBuilder [15]. More details on the simulation scope are described in Section 3.2 and the simulation inputs can be found in the appendix (Table A1).

This process results in the quantification of the toolbox, as we can provide numerical data on the potential energy reduction resulting from the implementation of each separate tool. These results are based on pre-calculated models and they can be different for each building. The method to obtain an overview for potential energy demand reduction in a building is explained, so that the figures can be used in future projects.

\subsection{Create a Roadmap to Use the Toolbox Data}

For the toolbox approach, it is crucial to understand what the parameters that shape decisions are and when the information of the energy reduction is useful for the designer. Important as the compilation of options provided by the toolbox might be, not all of them are applicable to every case. Furthermore, the designer can know at which points throughout the process the information is needed and what are the available options at that time.

\subsection{Confirm the Approach's Usability}

An important step in the methodology is the approach validation. Since the approach aims at supporting refurbishment strategy design, it should be validated by designers and building industry professionals involved in the decision-making process for refurbishment projects, which can potentially use the toolbox information. Therefore, validation will be conducted through interviews with refurbishment experts and stakeholders. They are presented with the approach and the relevant information and are asked to give feedback on its usability and suggest improvements.

\section{The Façade Refurbishment Toolbox Approach}

Information to support refurbishment decision-making often comes in the form of general suggestions, which are not always easy for the designer to incorporate in the decisions. Moreover, some of the information targets the occupants, owners, and public authorities, who are parties that influence or even 
determine the decisions made, but do not actively participate in the actual designing of the strategy. The proposed toolbox addresses these aspects, by focusing on the architect of the refurbishment strategy that makes decision on the design quality. In this paper, the compilation and quantification of the FRT, as well as its applicability, are presented.

\subsection{Compilation of Retrofitting Measures}

Before assessing the energy performance of the refurbished building, an overview of possible refurbishment measures has to be systematically organized. Such an overview can support shaping the design ideas and motivate to address all components. The options compiled aim at giving design solutions to upgrade the thermal envelope and translate general design principles and performance benchmarks into specific retrofitting measures. After identifying the key components for an integrated refurbishment strategy, solutions are given for each one. The measures are state-of-the art refurbishment solutions being used in refurbishment. Different measures are proposed for each component, based on refurbishment practice and experience, as well as literature review of research projects on refurbishment, such as EPIQR [16], TABULA [17], SUSREF [18], IFORE [19], and others [20].

The compilation of the measures resulted in the façade refurbishment toolbox. This toolbox is essentially a database of possible measures that can be implemented in refurbishment projects. The measures can be combined depending on the specific requirements of every project and design, resulting in the integrated refurbishment strategy. Addressing solutions for all the components composes integrated refurbishment strategies.

The goal of an integrated refurbishment is improving all components of the building envelope where heat losses occur; hence, the different retrofitting measures are organized in a matrix according to the component they address, as presented in Table 1. The options for each component are organized in separate parts for the existing condition and the retrofitting measures. Moreover options referring to renewable energy source (RES) or spatial interventions, such as the addition of elevators or extra floors, are mentioned separately. The measures are indicatively scaled according to effort and level of intervention. Measures that are more intervening and are, hence, expected to be more expensive are placed after the less intervening measures. In this way, each project can be located on the top, middle, or bottom of the table according to requirements. Moreover, the retrofitting measures are placed in the matrix according to the efficiency of the measure and the level of intervention, based on preliminary calculation [21]. This helps to easily identify the possible options depending on the projects ambitions and, thus, facilitate the selection. 
Table 1. The façade refurbishment toolbox matrix. The retrofitting measures refer to the building envelope, as well as building services.

\begin{tabular}{|c|c|c|c|c|c|c|c|}
\hline & \multicolumn{5}{|c|}{ Building Envelope } & \multicolumn{2}{|c|}{ Building Systems } \\
\hline & Exterior Wall & Window & Balcony & Roof & Ground Floor & Ventilation & Heat Source \\
\hline \multirow{3}{*}{$\begin{array}{c}\text { Existing } \\
\text { construction }\end{array}$} & $\begin{array}{c}\text { Masonry/cavity wall } \\
\text { no insulation }\end{array}$ & Single glazing & $\begin{array}{c}\text { Continuous slab, } \\
\text { no insulation } \\
\end{array}$ & $\begin{array}{l}\text { Pitched roof, timber rafters } \\
\text { no insulation/occupied loft }\end{array}$ & $\begin{array}{c}\text { Slab on ground, } \\
\text { no insulation } \\
\end{array}$ & Natural ventilation & Gas stove \\
\hline & $\begin{array}{c}\text { Lightweight } \\
\text { concrete/hollow brick, } \\
\text { no insulation } \\
\end{array}$ & Early, double-glazing & $\begin{array}{c}\text { Separate slab } \\
\text { no/little insulation }\end{array}$ & $\begin{array}{l}\text { Pitched roof, timber rafters } \\
\text { no insulation/unheated loft }\end{array}$ & $\begin{array}{c}\text { Basement unheated. } \\
\text { Concrete slab, } \\
\text { no insulation } \\
\end{array}$ & - & $\begin{array}{l}\text { Fossil fuel boiler in } \\
\text { each dwelling }\end{array}$ \\
\hline & Outdated insulation & - & - & $\begin{array}{c}\text { Concrete slab, } \\
\text { no/little/outdated insulation }\end{array}$ & little/outdated insulation & Trickle ventilation & Fossil fuel boiler per block \\
\hline \multirow{10}{*}{$\begin{array}{l}\text { Retrofitting } \\
\text { measures }\end{array}$} & Cavity insulation & Upgrade windows & Insulate balcony slab & $\begin{array}{c}\text { Pitched roof, no } \\
\text { insulation/unheated loft } \\
\end{array}$ & $\begin{array}{c}\text { Insulation on top of } \\
\text { ground/first floor slab }\end{array}$ & $\begin{array}{c}\text { Natural inlet/ } \\
\text { mechanical exhaust } \\
\end{array}$ & $\begin{array}{c}\text { Replace existing boiler in } \\
\text { each dwelling, high efficiency }\end{array}$ \\
\hline & Internal insulation & Secondary glazing single & Cut off balcony & Pitch roof insulation & $\begin{array}{c}\text { Insulation under } \\
\text { existing floor }\end{array}$ & $\begin{array}{c}\text { Mechanical } \\
\text { inlet/natural exhaust }\end{array}$ & $\begin{array}{c}\text { Replace existing boiler per } \\
\text { block, high efficiency }\end{array}$ \\
\hline & $\begin{array}{c}\text { Exterior Insulation and } \\
\text { Finishing Systems (EIFS) } \\
\end{array}$ & Secondary glazing double & $\begin{array}{c}\text { Balcony cladding- } \\
\text { Single glazing } \\
\end{array}$ & Insulation of top floor slab & - & Mechanical ventilation & CHP installation \\
\hline & Ventilated façade & - & $\begin{array}{c}\text { Balcony cladding- } \\
\text { Double glazing }\end{array}$ & Flat roof & - & $\begin{array}{c}\text { Ventilation } \\
\text { system with heat } \\
\text { recovery (HR) } \\
\end{array}$ & Heat pump \\
\hline & Timber-frame wall & $\begin{array}{c}\text { Replace windows } \\
\text { (Double pane) }\end{array}$ & - & Green roof & - & - & - \\
\hline & $\begin{array}{l}\text { Second Façade/ } \\
\text { Single glazing }\end{array}$ & Replace windows (Triple pane) & - & - & - & - & - \\
\hline & $\begin{array}{l}\text { Second Façade/ } \\
\text { Double glazing }\end{array}$ & Shading adjustable & - & - & - & - & Biomass boiler \\
\hline & BIPV's & - & - & Photovoltaic & - & - & Solar collectors \\
\hline & $\begin{array}{c}\text { Added space/Second } \\
\text { façade integrated }\end{array}$ & Shading fixed & Integrated balcony & - & - & - & Geothermy \\
\hline & Lift addition & Enlarged windows & New balcony & $\begin{array}{l}\text { Additional floor/ } \\
\text { occupied loft }\end{array}$ & $\begin{array}{c}\text { Additional } \\
\text { floor/occupied basement }\end{array}$ & - & District/community heating \\
\hline
\end{tabular}




\subsection{Quantification}

Apart from creating a catalog of the retrofitting measures, information to evaluate and compare them is needed. To this end, the measures are quantified, according to the energy saving, expressed as a percentage of the energy demand before. To quantify this effect, dynamic simulation is used. The software used for the thermal simulation is DesignBuilder [15]. There is a wide variety of software for building energy analysis [22]. DesignBuilder was chosen as appropriate for the purpose of this study, because it can generate a range of environmental performance and it provides a modeling interface, integrated with EnergyPlus, which is the U.S. DOE building energy simulation program for modeling building heating, cooling, lighting, ventilating, and other energy flows.

The assumptions used as input in the calculations were based on European standards, such as EN15251 [23]. They were regarding ventilation, heating and cooling, thermal comfort criteria, as well as values for internal gains and occupancy (Table A1). Based on the inputs, the building thermal performance was simulated on an hourly basis, throughout the year and gave results on the energy demand of the modeled building and the internal temperature. Since the toolbox quantification aimed at results that can be comparable, the simulation settings were kept fixed when simulating different measures, unless influenced by the type of retrofitting measure. For example, in the case of replacing the window, the infiltration rate was reduced, due to the assumption that the new windows are airtight. This means that the performance of each measure can be further optimized, if a high-resolution simulation, to predict more detailed performance, was required. This was, however, beyond the scope of the approach.

The measures are quantified in terms of heating energy demand, which represents more than half of the final energy consumption of residential buildings in the EU is used for space heating, reaching up to $70 \%$ in some countries $[1,24]$. This is the energy needed to balance the heat losses in order to maintain the required temperature. As a large part of heat losses are through the building envelope components, the retrofitting measures reduce these losses and, hence, the energy demand. Replacing the existing system with one of higher efficiency will result in additional savings in delivered and primary energy demand than the savings in heating energy demand already suggested by the toolbox calculation. To estimate the savings in primary energy, however, it is necessary to consider the fuel type or the energy mix, with the respective primary energy factor (PEF), as well as the system efficiency. This information is site-specific and cannot be generalized in the toolbox data.

To evaluate and compare refurbishment measures, each option needs to be quantified separately. Since this quantification is expressed as a reduction in current energy demand, the method used to isolate the impact of each option has two distinct steps. First, existing buildings were simulated, to determine the current energy demand. The building stock is not uniform and the existing condition of a building determines the energy demand. The toolbox calculations aim at covering a wide range of buildings and, therefore, a number of models where simulated, based on variations of the construction, position in the apartment block, window-to-wall ratio (WWR), and orientation. Overall there are six building types with regards to construction, six apartment types with regards to position, two window-to-wall ratios, and four orientations, resulting in 288 models. Each model, also referred to as building type, is the combination of one variation for each parameter of construction type, apartment position, window-wall ratio, and orientation. Even though these variations are not exhaustive, they are important to the future 
toolbox application, as any building can be associated with one of the existing models, to provide the indication of refurbishment impact.

After existing buildings variations were modeled, the building with the refurbishment measure applied was simulated, in order to give a numerical indication of the possible energy reduction that enables the comparison and supports the refurbishment strategy design. To isolate the measured effect, every option is simulated separately, by changing only one component in the model of the existing building. The toolbox options calculations generated specific figures on energy demand reduction related to each retrofitting measure.

The thermal transmittance coefficient $U$-value suggested for the retrofitted component and also considered during the calculations, has taken into account the legislation requirements set by the EPBD and its translation in the countries' national legislation. Table 2 presents the maximum $U$-values required in different countries and sets benchmark values, also used in the calculation in the next step of the approach development. Looking at the development of requirements in time, the tendency is to lower the $U$-value coefficient [25]. ECOFYS [26] recommended optimum $U$-values based on cost-efficiency and energy targets that, in most cases, are more ambitious than current national standards, suggesting that $U$-value requirements in most Member States should be made more demanding [1].

Table 2. Benchmark $U$-value for the building envelope, in different countries, and the toolbox approach.

\begin{tabular}{|c|c|c|c|c|c|c|c|c|c|c|c|}
\hline \multicolumn{2}{|c|}{ Component } & $\begin{array}{c}\text { Portugal } \\
\text { (1) }\end{array}$ & $\begin{array}{c}\text { Greece } \\
\text { (1) }\end{array}$ & $\begin{array}{c}\text { France } \\
\text { (1) }\end{array}$ & $\begin{array}{l}\text { Belgium } \\
\text { (1) }\end{array}$ & $\begin{array}{c}\text { Netherlands } \\
\text { (2) }\end{array}$ & $\begin{array}{l}\text { UK } \\
\text { (1) }\end{array}$ & $\begin{array}{c}\text { Germany } \\
\text { (3) }\end{array}$ & $\begin{array}{c}\text { Denmark } \\
\text { (1) }\end{array}$ & $\begin{array}{c}\text { Finland } \\
\text { (1) }\end{array}$ & $\begin{array}{c}\text { Toolbox } \\
\text { Benchmark }\end{array}$ \\
\hline Wall & & 0.50 & 0.40 & 0.43 & 0.35 & 0.28 & 0.30 & 0.24 & 0.20 & 0.17 & 0.2 \\
\hline Window & $U$-value & 3.30 & 2.60 & 2.00 & 2.20 & 2.20 & 2.00 & 2.00 & 1.8 & 1.00 & 2 \\
\hline Roof & $\left(\mathrm{W} / \mathrm{m}^{2} \mathrm{~K}\right)$ & 0.40 & 0.35 & 0.43 & 0.27 & 0.28 & 0.20 & 0.20 & 0.15 & 0.09 & 0.2 \\
\hline Floor & & 0.40 & 0.70 & 0.43 & 0.35 & 0.28 & 0.25 & 0.30 & 0.12 & 0.16 & 0.2 \\
\hline
\end{tabular}

(1) ([1], Figure 2B7); ${ }^{(2)}$ [27]; ${ }^{(3)}$ [28].

Based on the above discussion, the benchmark for the $U$-value achieved with the applied measures is $0.2 \mathrm{~W} / \mathrm{m}^{2} \mathrm{~K}$ for opaque elements and $2.0 \mathrm{~W} / \mathrm{m}^{2} \mathrm{~K}$ for transparent ones, which is equal or lower than the requirements in the countries within the study focus.

The following figure presents an overview of the potential savings as an effect of the retrofitting measures application. However, these percentages can vary in buildings that differ in the characteristics such as construction, window-to-wall ratio (WWR), and orientation. Based on the specific building characteristics, the FRT approach's available data provide an indication of the measure effect, expressed in percentage of heating energy demand reduction compared to the current demand [29]. As it can be observed in Figure 1, each measure results in a range of potential energy demand reduction. The exact percentage to be considered depends on the building's initial performance. The importance of those figures lies in their further applicability on specific projects. Based on the specific building characteristics, they can provide an indication of the measure effect, expressed as a percentage of heating energy demand reduction compared to the current demand. 


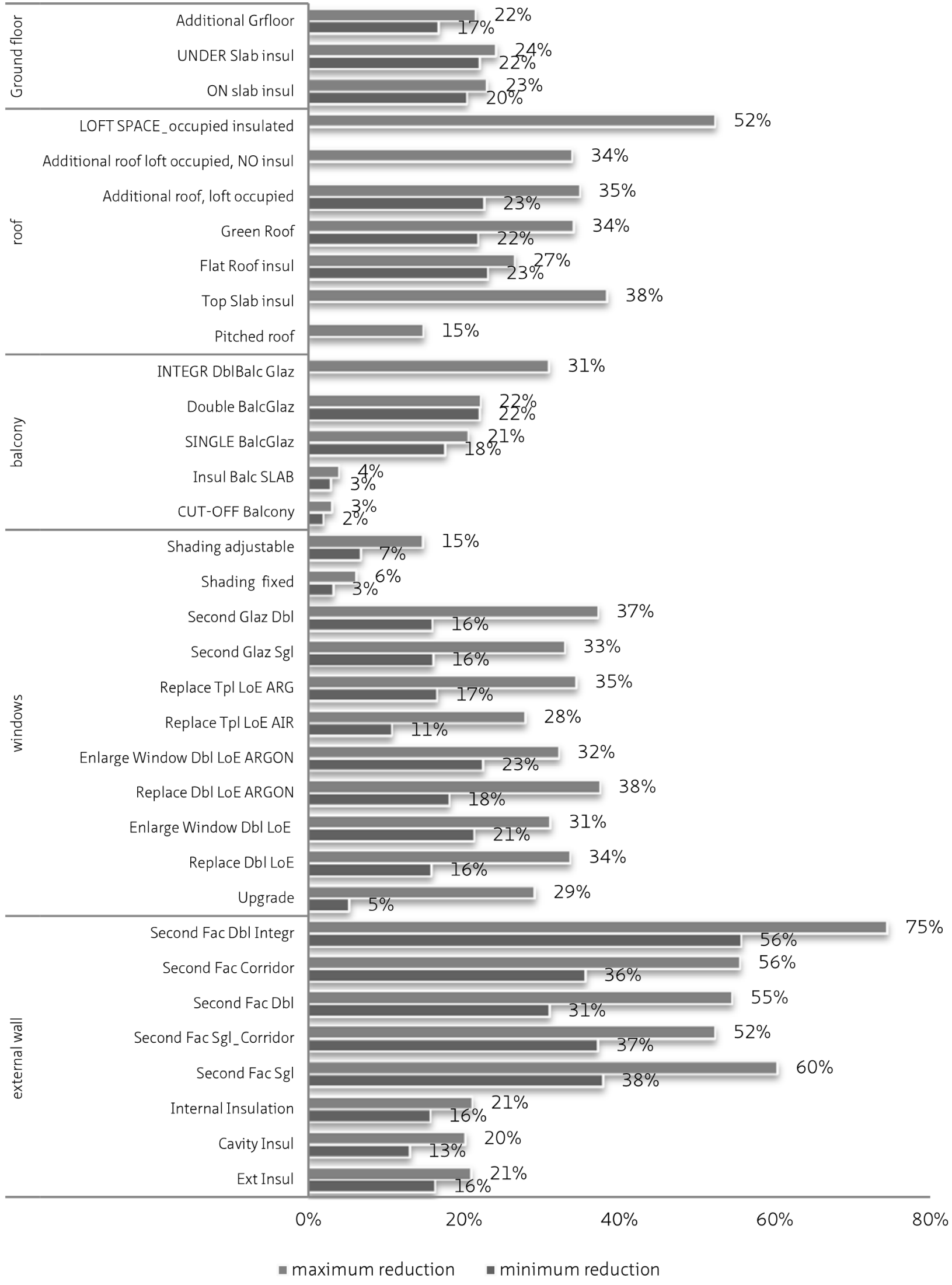

Figure 1. Overview of heating demand reduction after the application of retrofitting measures in the respective components. The values refer to typical apartment and they are average for different WWRs and orientation. 
In future projects, the building to be refurbished must be associated with the pre-calculated models according to each component construction, providing an indication of energy saving potential of different retrofitting measures without new simulations, to support the early stages of the design. Based on the pre-calculated models, the approach can provide percentages of energy demand reduction after the various measures application regarding each specific building. The steps to follow to obtain those data are shown in Figure 2. First, the existing construction, together with WWR and the façades orientation need to be identified. According to this information, the building can be associated with the pre-calculated model. Table 3 shows the building characteristics to be considered, in order to associate with the pre-calculated models.

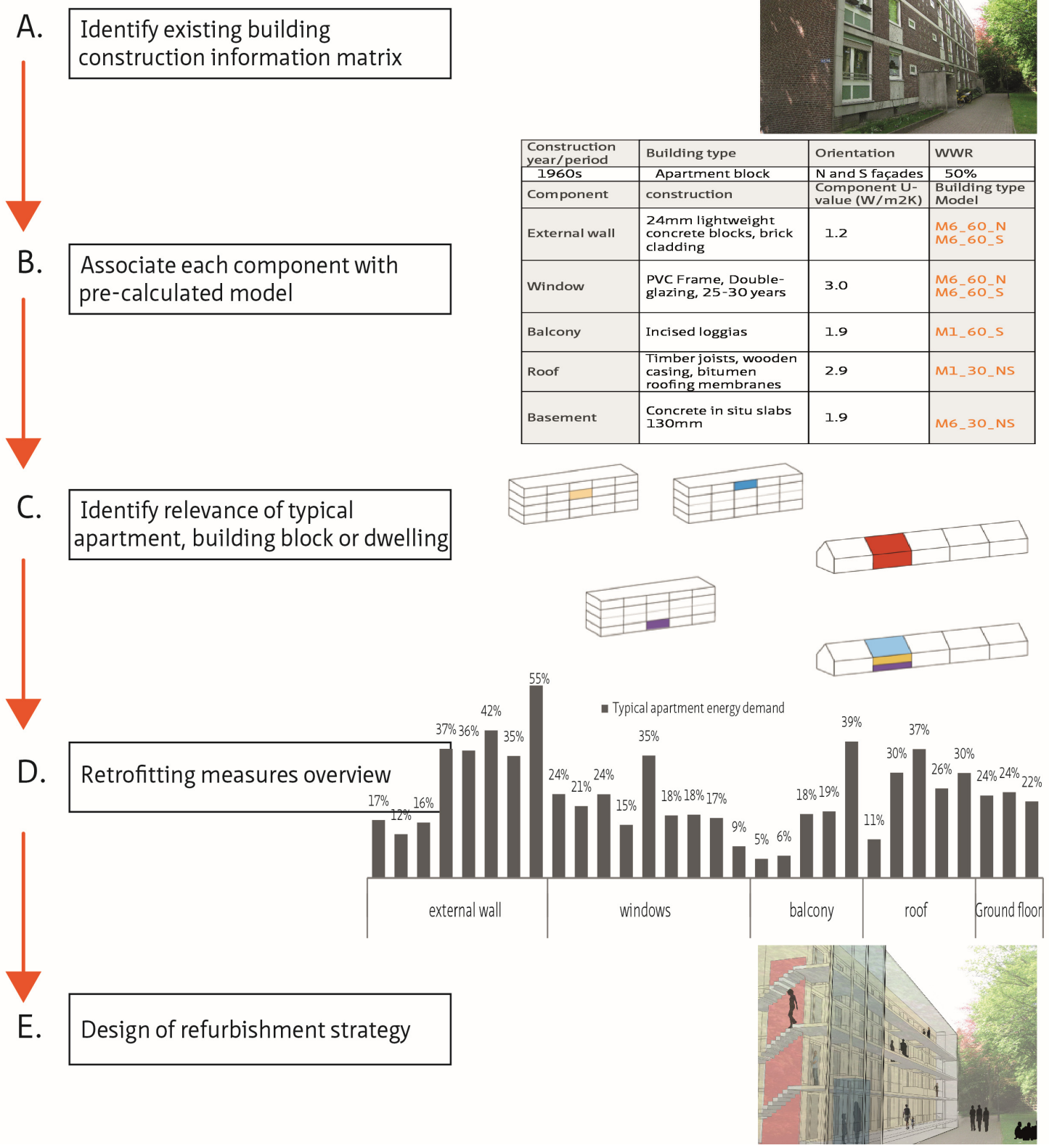

Figure 2. Steps to associate an existing building with the façade refurbishment toolbox (FRT) approach pre-calculated models. In this way, an indication of energy saving potential of different retrofitting measures is available without new simulations. 
Table 3. Building construction characteristics to be considered for the association with toolbox calculation models.

\begin{tabular}{|c|c|c|c|c|}
\hline Component & Existing Construction & Additional Parameter & $\begin{array}{c}\text { Component } \\
U \text {-Value }\left(\mathbf{W} / \mathbf{m}^{2} \mathbf{K}\right) \\
\end{array}$ & $\begin{array}{l}\text { WWR } \\
(\%)\end{array}$ \\
\hline \multirow{6}{*}{ External wall } & \multirow{2}{*}{$\begin{array}{l}\text { Masonry of solid brick or stone, } \\
250-400 \mathrm{~mm} \\
\text { two leaves of masonry with air cavity } \\
(30-50 \mathrm{~mm})\end{array}$} & \multirow[b]{2}{*}{$\mathrm{n} / \mathrm{a}$} & \multirow[b]{2}{*}{$2.5-1.4$} & $10-45$ \\
\hline & & & & $45-80$ \\
\hline & $\begin{array}{l}\text { Cavity. Inner leaf with lightweight } \\
\text { masonry units }\end{array}$ & \multirow[t]{2}{*}{ Single glazing } & \multirow{4}{*}{$1.4-0.6$} & $10-45$ \\
\hline & Perforated brick masonry & & & $45-80$ \\
\hline & \multirow{2}{*}{$\begin{array}{l}\text { Prefabricated concrete panels, insulation } \\
50 \mathrm{~mm}\end{array}$} & \multirow{2}{*}{ Double glazing } & & $10-45$ \\
\hline & & & & $45-80$ \\
\hline \multirow{4}{*}{ Window } & \multirow{2}{*}{ Single glazing } & \multirow{4}{*}{$\mathrm{n} / \mathrm{a}$} & \multirow{2}{*}{$6.5-5$} & $10-45$ \\
\hline & & & & $45-80$ \\
\hline & \multirow{2}{*}{ Double glazing } & & \multirow{2}{*}{$4.0-2.8$} & $10-45$ \\
\hline & & & & $45-80$ \\
\hline \multirow[b]{2}{*}{ Balcony } & \multirow{2}{*}{$\begin{array}{l}\text { Various construction (concrete slab, steel } \\
\text { structure) with no insulation, inducing } \\
\text { thermal bridges }\end{array}$} & \multirow[b]{2}{*}{$\mathrm{n} / \mathrm{a}$} & \multirow[b]{2}{*}{$2.0-0.8$} & $10-45$ \\
\hline & & & & $45-80$ \\
\hline \multirow[b]{2}{*}{ Roof } & $\begin{array}{l}\text { Pitched roof, Timber rafters, no } \\
\text { insulation in cavity }\end{array}$ & \multirow[b]{2}{*}{$\mathrm{n} / \mathrm{a}$} & $3.8-2.0$ & \multirow[b]{2}{*}{ all } \\
\hline & $\begin{array}{l}\text { Flat roof, plaster, } 130-160 \mathrm{~mm} \\
\text { reinforced concrete slab, } 20-40 \mathrm{~mm} \\
\text { insulation, screed }\end{array}$ & & $0.6-1.0$ & \\
\hline \multirow{2}{*}{ Ground floor } & \multirow{2}{*}{$\begin{array}{l}\text { Various construction (concrete slab, steel, } \\
\text { timber structure) with no insulation }\end{array}$} & $\begin{array}{l}\text { External wall type } 1 \\
\text { (masonry, cavity) }\end{array}$ & \multirow{2}{*}{$2.0-0.8$} & \multirow{2}{*}{ all } \\
\hline & & $\begin{array}{c}\text { External wall type } 2 \\
\text { (lightweight masonry) }\end{array}$ & & \\
\hline
\end{tabular}

Moreover, it needs to be determined whether it is relevant to look at the typical apartment or the whole building. In most cases, particularly in apartment buildings, the savings of the typical apartment are a better indication to consider in the decision-making, as the effect of the measure is greater than in other types. Nevertheless, depending on the building type and the objectives of the design team, the whole building consumption may be also relevant. Finally, the percentage of potential energy demand reduction for each component retrofitting measure can be obtained be referring to the simulation results of the respective building types [29], composing the measures overview graph, similar to the one in Figure 1, but for a specific building.

\section{Usability of the Approach}

Every refurbishment project is different, not only in terms of the existing building's condition and the relevant energy savings, as they were calculated in by the FRT approach, but also regarding the project specifications. Those specifications include the required performance of the refurbished building, modifications of building's appearance, function and layout, as well as investment and changes 
in the occupants' situation. Since the FRT is a systematic approach to support decision-making in the design process, it is still crucial to understand what the parameters that shape decision are and when the information of the possible energy reduction can be useful for the designer. Important as the systematic compilation of options provided by the toolbox may be, not all of them are applicable to every case. Furthermore, the designer needs to know at which points throughout the process the information comes together and what the available options are. The goal is the development of integrated refurbishment strategies, while stimulating critical thinking and arguments to support informed decisions that take into account the project specifications and energy demand reduction. For this reason, the next steps in the approach highlight how these data can be integrated in the design process and finally the usability of the information was evaluated.

\subsection{A Roadmap to Use the FRT Data}

Given the necessity to support the design decisions at the early stages, the approach points out which decisions are made during the strategy development and what parameters are affecting them. Those parameters are related not only to the original condition of the building, but also the specific requirements of each project. Such requirements and limitations are, amongst others, the monumental status, that allows for modification of the appearance or not, the building program of the project, e.g., if extra space is required, the budget and the lifespan of the investment, the user position during and after the refurbishment, and the energy efficiency of the refurbished building.

Every design process has to consider and give solution to several requirements. In order for the designer to use the information provided by the toolbox approach, they need to know how the information contributes to their design process. Organizing the steps where the impact of the information is possible leads to a roadmap to the refurbishment design process. A roadmap is defined as a plan or strategy intended to achieve a particular goal. Roadmapping is used in several disciples as an effective process and for coordinating planning and strategy, as well as a communication tool [30]. In the present approach, the roadmap is used to highlight key considerations in the decision-making process for refurbishment strategies and explain how the toolbox information facilitate the process, either by identifying available options or providing specific figures about the energy demand reduction.

Even though the process is not necessary linear, nor do the considerations always appear in this order, it is still indicative for the process. Assessing the existing condition and the need to upgrade comes first. Then specifications of the project, such as the external appearance, dwelling quality, residents etc. come into the scope. The points of investment and energy savings are often interchangeable in order. The decision on a specific measure can be based on the project budget and ambition and then check its efficiency or a measure can be selected on the grounds of high energy savings and its feasibility will be then decided according to the investment.

The key considerations are regarding the existing building condition, the possibility to change the appearance, the building program, the energy savings, the level of investment and the options for energy generation. Figure 3 presents the refurbishment toolbox roadmap in the form of a flowchart, consisting of those key considerations. The flowchart includes questions and answers about those key points. The toolbox information can have input on that considerations, depending on the respective answers. During the design of a refurbishment strategy, it was proven that the energy reduction cannot always be the only 
decisive factor. Some of the options already had to be excluded, due to other parameters, such as the monumental status, extra space required, the budget etc.

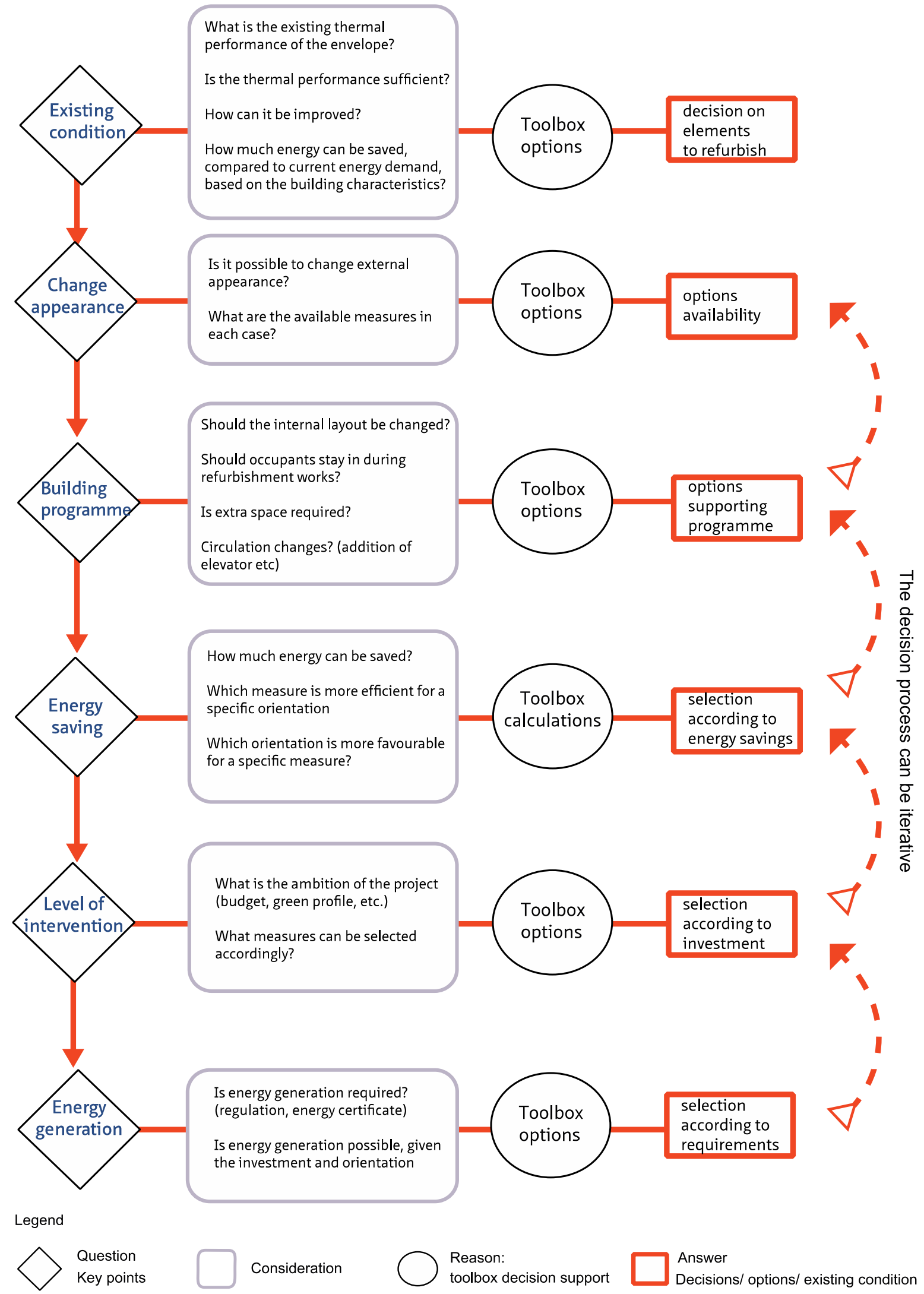

Figure 3. The roadmap to façade refurbishment toolbox. 


\subsection{Endorsement Through Interview}

The usability of the approach and particularly the energy saving potential overview were validated by building industry professionals, who are expected to use it in refurbishment strategy decision-making. The information sought was of a qualitative nature, as they refer to the design process and the usability of the approach. Therefore, semi-structured interviews were used as a means of qualitative data collection. The first part of the interview got the respondents acquainted with the approach, while in the second phase, they were asked on their opinion regarding the refurbishment design process and the impact of the toolbox information.

The main categories of respondents are designers and stakeholders, divided into different groups. Since the approach focuses on the design phase, architects were an important respondent group to provide feedback. Additionally architectural students working on refurbishment projects were part of the designers' category. Aside from designers, decisions are influenced by other building industry parties, referred to as stakeholders. The respondents were selected on the basis of their experience on refurbishment decision-making. The groups include housing companies' representatives that are often the refurbishment initiator and shape the specification, together with maintenance and renovation constructors and climate consultant. Table 4 presents the different groups of respondents and the respective numbers. Designers outnumber the other groups, as they are the target of the developed methodology.

Table 4. Respondent groups interviewed.

\begin{tabular}{l|c|l}
\hline \multicolumn{1}{c|}{ Respondents Group } & No. Respondents & \multicolumn{1}{c}{ Influence on Design Decisions } \\
\hline Architectural students & 10 & $\begin{array}{l}\text { Design development. Strategy concept. Combination of different } \\
\text { parameters of function and performance }\end{array}$ \\
\hline Architect/designers & 6 & $\begin{array}{l}\text { Initiator of refurbishment. Formulation of specification. Definitions of } \\
\text { solution feasibility. Evaluation of final solution benefits for the user. }\end{array}$ \\
\hline $\begin{array}{l}\text { House owner/consumer } \\
\text { Housing association } \\
\text { representatives }\end{array}$ & 4 & $\begin{array}{l}\text { Initiator of refurbishment. Formulation of specification. Definitions of } \\
\text { solution feasibility. Evaluation of added value of solution for the estate }\end{array}$ \\
\hline $\begin{array}{l}\text { Refurbishment } \\
\text { contractors }\end{array}$ & 2 & Design execution. Definitions of solution feasibility \\
\hline Energy consultant & 1 & Evaluation of energy performance. Influence on design development \\
\hline
\end{tabular}

The interviews showed that energy upgrade is typically part of the project requirements. However, in most cases it does not influence the concept development and comes as an additional parameter to be incorporated in the final design. Efforts toward reversing this process are taking place, particularly from the stakeholders' point of view. Multi-disciplinary teams, often, but not always, with the participation of architects, aim at making refurbishment decisions based on the solution performance. Stakeholders appear to be more aware, compared to architects, of the need to integrate the energy performance in their decisions. The reason is the direct relation of energy savings and cost, which is the most decisive factor for stakeholders. Housing companies and refurbishment consultants are already using tools to get early indicators of performance, while architects mostly rely on their experience and general knowledge. In this context, the approach focus on architects is justified.

In general, the participants believed that the toolbox information is useful to provide an overview of possibilities and arguments within the design team. Even if the decision is not on the measure with the 
higher energy savings, it is beneficial that it triggers the discussion on why an efficient measure is not selected. On the other hand, it can direct the design towards high-saving options. Most importantly, the information can be valuable when negotiating possible options with clients. Table 5 provides an overview of the questions and the answers during the semi-structures interviews.

Table 5. Overview of the semi-structured interview questions and responses.

\begin{tabular}{|c|c|c|}
\hline Topic & Interview Questions & Answers/Remarks \\
\hline \multirow{12}{*}{$\begin{array}{l}\text { Design } \\
\text { process }\end{array}$} & \multirow{4}{*}{$\begin{array}{l}\text { What are the parameters normally considered } \\
\text { in t refurbishment project? }\end{array}$} & $\begin{array}{l}\text { Improving collective spaces (entrances etc.), improve } \\
\text { appearance, reduce vacancy of apartments. }\end{array}$ \\
\hline & & Replace bathroom kitchen, interior finishing \\
\hline & & Minimum required energy upgrade \\
\hline & & Homeowners more concerned with energy reduction. \\
\hline & \multirow{3}{*}{$\begin{array}{l}\text { What are the parties that take the decisions, } \\
\text { in each phase? }\end{array}$} & Architect in design phase \\
\hline & & Client/Owner final decision \\
\hline & & The design team provide options to the client \\
\hline & \multirow{3}{*}{$\begin{array}{l}\text { Is the energy upgrade a requirement of } \\
\text { the strategy? }\end{array}$} & Yes, but not the main motivation. \\
\hline & & $\begin{array}{l}\text { The question of energy upgrade was not an "if" but more } \\
\text { a "how" }\end{array}$ \\
\hline & & $\begin{array}{l}\text { Usually minimum compatibility with regulations is } \\
\text { only needed }\end{array}$ \\
\hline & \multirow{2}{*}{$\begin{array}{l}\text { At which point during the design process is } \\
\text { the energy upgrade considered? }\end{array}$} & $\begin{array}{l}\text { The requirement is there in the beginning and is considered } \\
\text { again at late phase, when calculations are needed }\end{array}$ \\
\hline & & $\begin{array}{l}\text { To make a decision, after several options were considered, an } \\
\text { approximation of the effect is needed }\end{array}$ \\
\hline \multirow{14}{*}{$\begin{array}{l}\text { Usability } \\
\text { of FRT }\end{array}$} & \multirow{3}{*}{$\begin{array}{l}\text { Are the approach and the information } \\
\text { easily comprehensive? }\end{array}$} & The approach and the information are clear \\
\hline & & The overview is detailed enough to provide an indication \\
\hline & & More information about what each calculated measure means \\
\hline & \multirow{4}{*}{$\begin{array}{l}\text { Does the toolbox database help in organizing } \\
\text { possible options }\end{array}$} & The already known options that the toolbox confirmed \\
\hline & & Reminded of options and components to be addressed. \\
\hline & & Helped in thinking why to do or not to do a measure. \\
\hline & & Remind to consider the energy aspect \\
\hline & $\begin{array}{l}\text { 7. Did you consider the overview and potential } \\
\text { energy reduction provided by the FRT during } \\
\text { the design phase of a current project? }\end{array}$ & $\begin{array}{l}\text { Yes, for project at the early stages, e.g., in trying to convince } \\
\text { clients to consider a measure because of the bigger } \\
\text { potential saving }\end{array}$ \\
\hline & $\begin{array}{l}\text { Regarding one of your past projects, do you } \\
\text { believe the decisions taken would be changed } \\
\text { due to the toolbox information? }\end{array}$ & $\begin{array}{l}\text { Probably not. The selected measures have already been } \\
\text { decided, based on specific reasons. After the concept design } \\
\text { it is difficult to make changes in the principals of the strategy }\end{array}$ \\
\hline & $\begin{array}{l}\text { 9. What type of information would be useful } \\
\text { for you? }\end{array}$ & $\begin{array}{l}\text { The energy saving information are useful particularly if they } \\
\text { were combined with cost }\end{array}$ \\
\hline & Do you think the information about the & $\begin{array}{l}\text { Useful arguments in discussion with the different parties } \\
\text { involved (owners, users, constructors, services experts etc.) }\end{array}$ \\
\hline & $\begin{array}{l}\text { potential energy upgrade can help support } \\
\text { your design decisions? }\end{array}$ & $\begin{array}{l}\text { The energy savings need to be balanced against the cost of } \\
\text { the measure }\end{array}$ \\
\hline & Do the key points highlighted in the roadmap & $\begin{array}{l}\text { Can be used as a checklist to be reminded the aspect } \\
\text { to consider. }\end{array}$ \\
\hline & $\begin{array}{l}\text { reflect considerations you have during the } \\
\text { design process? }\end{array}$ & $\begin{array}{l}\text { the key points are relevant., but come up with different order, } \\
\text { not linear }\end{array}$ \\
\hline
\end{tabular}


The investment cost came up several times during the interviews, as the main factor to determine the decisions taken by the client. Even though the approach does not provide specific numbers for the cost of a measure, it addresses its importance as a parameter in the matrix organization. Measures that are more intervening and are, hence, expected to be more expensive are placed after the less intervening measures. Calculating the expense of a measure it is not possible within the scope of the approach as it depends on the specific project, in terms of scale, location, detailing of the solution etc. Nevertheless, when a specific project is considered and the expenses are known, the toolbox information can easily give an indicative payback time, based on the calculated energy savings.

\section{Conclusions}

The present study developed a façade refurbishment toolbox (FRT) to support the decision-making process for the design. The FRT approach provides information that can support the decision-making of residential façade refurbishment strategies. The information has two aspects; the organization of available measures, on one hand, and their quantification and comparison on the other. First, the systematic compilation of retrofitting measures, organized in a matrix, can help to acknowledge available options and support choosing or rejecting them, according to the different parameters and key considerations. Furthermore, the approach has calculated the energy reduction related to each measure application, quantifying them according to their efficiency.

As a result, the toolbox calculations provide an indication of the potential energy demand reduction at the early stages of the design and give the possibility to compare different measures when decisions need to be taken. Additionally, the toolbox matrix helps in organizing the available options and highlight key considerations during the process that the toolbox information can have an impact on. The design team is provided with information on the energy performance in the early stages rather that after most design decisions have already been made, which is often the case in current practice. The approach primarily targets the architect, that has to make the design development, but the information can also be used by users, owners, and other stakeholders.

To confirm the approach's further applicability, building industry experts, designers, and stakeholders were interviewed to give feedback on the qualitative assessment of the approach usability. The respondents were selected on the basis of their experience on refurbishment decision-making. Both designers and stakeholders have found the energy saving potential and the level of information provided by the approach useful information, not only during their own decision-making, but also in their argumentation within the project team and the client.

The approach provides a general, but clear, idea for the effect of different measure, by quantifying measure impact on energy demand. If more specific data on energy consumption are needed, simulating the performance of the final strategy is required. Nevertheless, this does not conflict with the objective of the FRT, which aims at providing an indication at the early stages of the design. The integration of measures' cost is recommended as further development of the toolbox. Additional consideration that influence the decisions, particularly form the architects' perspective, included the improvement of a building's function and appearance, the flexibility of the solution to be adjustable to occupants' needs and the preservation of building existing value. 
Ensuring future usability of the approach depends on more parameters, such as accessibility of the information, willingness of the practitioners, user interface etc. Further development of the approach, incorporating additional information and aspects, such as combined solutions of measures, cost calculations, different climate adaptation, etc., have the potential of extending the approach usability.

The FRT information can support the decision, integrating the energy savings to the project specifications, leading to the design of energy conscious refurbishment strategies for the residential buildings' façades. The approach objective is neither to generate ready-made solutions nor to suggest one that is optimal from the energy point of view alone. Given the wide range of combination of measures and the parameters that vary in every project, the approach aims at incorporating energy savings as a factor that facilitates and supports the design. In this way, architects can get used to take the energy performance, together with the numerical output of the toolbox information, into account in their decision-making process.

\section{Acknowledgments}

The research presented in this paper is part of the $\mathrm{PhD}$ research conducted in Faculty of Architecture and the Built Environment, The Delft University of Technology, during the period 2010-2014, titled: "Façade Refurbishment Toolbox: Supporting the Design of Residential Energy Upgrades". The author would like to thank the promotors of the PhD research, U. Knaack and A. van Timmeren, as well as Tilllmann Klein, leader of the Façade Research Group, for their support and contribution during the development of the research.

\section{Conflicts of Interest}

The author declare no conflict of interest.

\section{Appendix}

\section{A.1. Simulation Inputs}

The input categories are organised according to the requirements of the simulation software used, DesignBuilder, as presented in Table A1. Different simulation software might require different input categories, but the nature of the data would be similar. They were decided based on European standards, for example in the case of indoor comfort and ventilation, as well as assumption, such as for the apartment occupancy.

The functions of heating, ventilation, lighting etc. and the resulting energy demand of the systems are simulated. A standard hot water radiator system is used. The existing building is naturally ventilated, through the modelled openings. The ventilation strategy, according to EN14788 [31], is to provide a continuous, relatively low background ventilation air flow rate together with a higher intermittently operated extract air flow rate in the activity rooms, such as the kitchen and the bathroom. In practice this constant air flow will be achieved either by trickle ventilators or by windows “cracked” open [32]. Even though higher infiltration rates can be assumed in existing buildings, extreme infiltration rate were not used in the simulation, to avoid affecting considerably the results and the comparability of the options. 
Part of the research boundary conditions is to focus on the north-west European climate, classified as moist mid-latitude climate, with adequate precipitation in all months and no dry season (Cfb), according to Köppen climate classification system [33]. The weather data used in the simulation refer to Amsterdam, The Netherlands. The Netherlands climate is. Climates with the same classification are encountered in Germany, France, United Kingdom, Austria and other European countries [34].

\section{A.2. Simulation Outputs}

Based on the information used as inputs, hourly data on the building performance throughout the year were generated. The data used to evaluate the current building condition are heating energy demand and internal temperature. The energy demand is calculated in $\mathrm{kWh} / \mathrm{m}^{2}$ per year and it refers to the living and bedroom of the dwelling.

The internal temperature of the zones, as simulated in an hourly basis, is also checked, in order to ensure thermal comfort. According to [35], the comfort zone is defined in terms of a range of operative temperatures that people find thermally acceptable Acceptable thermal comfort limits, according to ISO7730 [36], are considered $24.5 \pm 1.5^{\circ} \mathrm{C}$ for summer and $22.0 \pm 2.0^{\circ} \mathrm{C}$ for winter.

Table A1. Inputs for each zone of the modelled apartment. The inputs are organized according to the requirements of the simulation software.

\begin{tabular}{|c|c|c|c|c|c|c|c|c|}
\hline & Living & Bedroom1 & Bedroom2 & Kitchen & $\begin{array}{c}\text { Bathroo } \\
\text { m }\end{array}$ & Hall & Basement & Roof \\
\hline Zone type & $\begin{array}{c}\text { Standard, } \\
\text { conditione } \\
\text { d }\end{array}$ & $\begin{array}{c}\text { Standard, } \\
\text { conditioned }\end{array}$ & $\begin{array}{l}\text { Standard, } \\
\text { conditioned }\end{array}$ & $\begin{array}{l}\text { Standard, } \\
\text { conditioned }\end{array}$ & $\begin{array}{c}\text { Standard, } \\
\text { conditione } \\
\text { d }\end{array}$ & $\begin{array}{c}\text { Standard, } \\
\text { conditioned }\end{array}$ & $\begin{array}{c}\text { Semi- } \\
\text { exterior, } \\
\text { uncondit. }\end{array}$ & $\begin{array}{c}\text { Semi- } \\
\text { exterior, } \\
\text { uncondi. }\end{array}$ \\
\hline $\mathrm{m}^{2}$ & 19.5 & 18.4 & 13 & 7 & 5.2 & 11 & 0 & 0 \\
\hline $\begin{array}{c}\text { Occupancy } \\
\text { (nr of people) }\end{array}$ & 4 & 2 & 2 & 2 & 1 & 2 & - & - \\
\hline $\begin{array}{c}\text { Density } \\
\text { (people/m²) }\end{array}$ & 0.2 & 0.1 & 0.15 & 0.28 & 0.19 & 0.181 & 0 & 0 \\
\hline Schedule & $15-23$ & $22-9$ & $22-9$ & $24 / 0.2$ & $24 / 0.1$ & $24 / 0.2$ & \multicolumn{2}{|c|}{$\mathrm{n} / \mathrm{a}$} \\
\hline Metabolic & 0.8 & 0.8 & 0.8 & 0.8 & 0.8 & 0.8 & 0 & 0 \\
\hline \multicolumn{9}{|c|}{ Environmental Control (1) } \\
\hline $\begin{array}{c}\text { Heating } \\
\text { Set-point }{ }^{\circ} \mathrm{C}\end{array}$ & 20 & 20 & 20 & 18 & 18 & 18 & $\mathrm{n} / \mathrm{a}$ & $\mathrm{n} / \mathrm{a}$ \\
\hline $\begin{array}{c}\text { Cooling } \\
\text { Set-point }{ }^{\circ} \mathrm{C} \\
\end{array}$ & 26 & 26 & 26 & 26 & 26 & 26 & $\mathrm{n} / \mathrm{a}$ & $\mathrm{n} / \mathrm{a}$ \\
\hline $\begin{array}{c}\text { Natural } \\
\text { Ventilation }{ }^{\circ} \mathrm{C}\end{array}$ & 23 & 23 & 23 & 23 & 23 & 23 & $\mathrm{n} / \mathrm{a}$ & $\mathrm{n} / \mathrm{a}$ \\
\hline $\begin{array}{l}\text { Mechanical } \\
\text { Ventilation }\end{array}$ & low & low & low & low & low & low & $\mathrm{n} / \mathrm{a}$ & $\mathrm{n} / \mathrm{a}$ \\
\hline
\end{tabular}


Table A1. Cont.

\begin{tabular}{|c|c|c|c|c|c|c|c|c|}
\hline & Living & Bedroom1 & Bedroom2 & Kitchen & Bathroom & Hall & Basement & Roof \\
\hline \multicolumn{9}{|c|}{ Minimum Fresh Air (2) } \\
\hline $\begin{array}{c}\text { fresh air } \\
\text { (L/s/person) }\end{array}$ & 7 & 7 & 7 & 10 & 15 & 7 & 0 & 0 \\
\hline $\begin{array}{c}\text { Mechanical } \\
\text { ventilation per } \\
\text { area }\left(\mathrm{L} / \mathrm{s} / \mathrm{m}^{2}\right)\end{array}$ & 0.42 & 0.42 & 0.42 & 0.42 & 0.42 & 0.42 & 0 & 0 \\
\hline \multicolumn{9}{|l|}{ Lighting } \\
\hline $\operatorname{Lux}^{(3)}$ & 200 & 100 & 100 & 500 & 200 & 100 & & \\
\hline $\mathrm{W} / \mathrm{m}^{2}(4)$ & 9 & 9 & 9 & 9 & 9 & 4.5 & & \\
\hline $\begin{array}{c}\text { Equipment } \\
\text { intern. gain } \\
\mathrm{W} / \mathrm{m}^{2}(5) \\
\end{array}$ & 5 & 5 & 5 & 30 & 5 & 0 & 0 & 0 \\
\hline \multicolumn{9}{|l|}{ Airtightness } \\
\hline $\begin{array}{l}\text { Infiltration rate } \\
\mathrm{m}^{3} / \mathrm{h}_{\text {per }} \mathrm{m}^{2} \text { ex. } \\
\text { surface }^{(6)}\end{array}$ & 5 & 5 & 5 & 5 & 5 & 5 & 5 & 5 \\
\hline
\end{tabular}

(1) [23] Table A.3; ${ }^{(2)}$ [23] Table B.5; ${ }^{(3)}$ [37] Tables 5.1.3, 5.12.5, 5.2.4, 5.36.17; ${ }^{(4)}$ [38] Tables 3.2; ${ }^{(5)}$ [32] Table 6.2; (6) [39] Table B.1.

\section{References}

1. Building Performance Institute Europe. Europe's Buildings under the Microscope; Building Performance Institute Europe: Brussels, Belgium, 2011.

2. European Commission. A Roadmap for Moving to a Competitive Low Carbon Economy in 2050; European Commission, DG for Energy: Brussels, Belgium, 2011.

3. Gaterell, M.R.; McEvoy, M.E. The impact of climate change uncertainties on the performance of energy efficiency measures applied to dwellings. Energy Build. 2005, 37, 982-995.

4. Eurostat. "Consumption of Energy"-Statistics Explained. Available online: http://epp.eurostat.ec. europa.eu/statistics_explained/index.php/Consumption_of_energy (accessed on 4 August 2015).

5. Rademaekers, K.; Boonekamp, P.; Harmsen, R.; Boeve, S.; Sijm, J. The Energy Efficiency Investment Potential for the Building Environment: Two Approaches; Ecorys for DG Energy: Rotterdam, The Netherlands, 2012.

6. European Directive 2010/31/EU. On the Energy Performance of Building; The European Parliament and of the Council: Brussels, Belgium, 2010.

7. European Commission. Financing the Energy Renovation of Buildings with Cohesion Policy Funding; European Commission, DG for Energy: Brussels, Belgium, 2014.

8. Ma, Z.; Cooper, P.; Daly, D.; Ledo, L. Existing building retrofits: Methodology and state-of-the-art. Energy Build. 2012, 55, 889-902.

9. Ferreira, J.; Pinheiro, M.D.; Brito, J.D. Refurbishment decision support tools: A review from a portuguese user's perspective. Constr. Build. Mater. 2013, 49, 425-447.

10. Cooper, R.; Aouad, G.; Lee, A.; Wu, S.; Fleming, A.; Kagioglou, M. Process Management in Design and Construction; Blackwell Publishing Ltd: Oxford, UK, 2005. 
11. Industrial Advisory Ad-Hoc. Energy-Efficient Buildings PPP beyond 2013: Research \& Innovation Roadmap; Energy Efficient Buildings Association: Brussels, Belgium, 2012.

12. Attia, S.; Gratia, E.; de Herde, A.; Hensen, J.L.M. Simulation-based decision support tool for early stages of zero-energy building design. Energy Build. 2012, 49, 2-15.

13. Riether, G.; Butler, T. Simulation space. In eCAADe 2008: Architecture "in Computro", Integrating Methods and Techniques Education and Research in Computer Aided Architectural Design in Europe; The Higher Institute of Architectural Science: Antwerp, Belgium, 2008; pp. 133-142.

14. Attia, S. A Tool for Design Decision Making Zero Energy Residential Buildings in Hot Humid Climates; Université catholique de Louvain: Louvain, Belgium, 2012.

15. DesignBuilder. Designbuilder, 3.0.0.064; DesignBuilder Software Ltd.: Stroud, UK, 2012.

16. Flourentzou, F.; Genre, J.-L.; Roulet, C.-A. Epiqr-tobus: A new generation of refurbishment decision aid methods. In Towards Sustainable Building; Maiellaro, N., Ed.; Springer Science+Business Media: Dordrecht, The Netherlands, 2001; Volume 61, pp. 161-169.

17. Typology Approach for Building Stock Energy Assessment. Typology approach for building stock energy assessment. Main results of the TABULA project-Final project Report. In First TABULA Synthesis Report; Tabula, P.T., Ed.; Institut Wohnen und Umwelt Gmb: Darmstadt, Germany, 2012.

18. Häkkinen, T. Systematic method for the sustainability analysis of refurbishment concepts of exterior walls. Constr. Build. Mater. 2012, 37, 783-790.

19. Sdei, A.; Tittelein, P.; Lassue, S.; McEvoy, M.E. Dynamic Thermal Modeling of Retrofitted Social Housing in England and France. In Proceedings of the CLIMA 2013: 11th REHVA World Congress and the 8th International Conference on Indoor Air Quality, Ventilation and Energy Conservation in Buildings, Prague, Czech Republic, 16-19 June 2013; Karel Kabele, M.U., Suchý, K., Lain, M., Eds.; Society of Environmental Engineering (STP): Prague, Czech Republic, 2013; p. 6882.

20. Nemry, F.; Uihlein, A.; Colodel, C.M.; Wetzel, C.; Braune, A.; Wittstock, B.; Hasan, I.; Kreiflig, J.; Gallon, N.; Niemeier, S.; et al. Options to reduce the environmental impacts of residential buildings in the european union-Potential and costs. Energy Build. 2010, 42, 976-984.

21. Konstantinou, T.; Knaack, U. An approach to integrate energy efficiency upgrade into refurbishment design process, applied in two case-study buildings in northern european climate. Energy Build. 2013, 59, 301-309.

22. Building Energy Software Tools Directory. Available online: http://apps1.eere.energy.gov/ buildings/tools_directory/subjects.cfm/pagename=subjects/pagename_menu=whole_building_ana lysis/pagename_submenu=energy_simulation (accessed on 11 March 2015).

23. EN 15251 Indoor Environmental Input Parameters for Design and Assessment of Energy Performance of Buildings Addressing Indoor Air Quality, Thermal Environment, Lighting and Acoustics; European Commitee for Standardization (CEN): Brussels, Belgium, 2007.

24. Itard, L.; Meijer, F. Towards a Sustainable Northern European Housing Stock; IOS Press: Amsterdam, The Netherlands, 2008; Volume 22, p. 213.

25. Hegger, M.; Fuchs, M.; Stark, T.; Zeumer, M. Energy Manual: Sustainable Architecture; Birkhäuser: Basel, Switzerland, 2008.

26. Boermans, T.; Petersdorff, C. U-Values for Better Energy Performance of Buildings; Ecofys by order of Eurima-European Insulation Manufacturers Association: Cologne, Germany, 2007. 
27. Bouwbesluit: Artikel 5.3 Thermische Isolatie. Available online: http://www.bouwbesluiton line.nl/Inhoud/docs/wet/bb2012_nvt/artikelsgewijs/hfd5/afd5-1/art5-3 (accessed on 5 June 2015).

28. Anforderungen bei Änderung von Außenbauteilen und bei Errichtung Kleiner Gebäude; Randbedingungen und Maßgaben für die Bewertung Bestehender Wohngebäude. Available online: http://www.enev-online.org/enev_2009_volltext/enev_2009_anlage_03_anforderungen_aenderung_ aussenbauteile.htm\#Anlage 3_Nr_7._Anforderungen (accessed on 9 November 2015).

29. Konstantinou, T. Facade Refurbishment Toolbox: Supporting the Design of Residential Energy Upgrades. Ph.D. Thesis, Delft University of Technology, Delft, The Netherlands, 2014.

30. Lee, J.H.; Kim, H.-I.; Phaal, R. An analysis of factors improving technology roadmap credibility: A communications theory assessment of roadmapping processes. Technol. Forecast. Soc. Chang. 2012, 79, 263-280.

31. EN 14788 Ventilation for Buildings—Design and Dimensioning of Residential Ventilation Systems; European Standarisation Comitee (CEN): Brussels, Belgium, 2006.

32. The Chartered Institution of Building Services Engineers. Guide A: Environmental Design; CISBE: London, UK, 2006.

33. Peel, M.C.; Finlayson, B.L.; McMahon, T.A. Updated world map of the köppen-geiger climate classification. Hydrol. Earth Syst. Sci. 2007, 11, 1633-1644.

34. Kottek, M.; Grieser, J.; Beck, C.; Rudolf, B.; Rubel, F. World map of the Köppen-Geiger climate classification updated. Meteorol. Z. 2006, 15, 259-263.

35. ASHRAE Standard 55-2004 Thermal Environmental Conditions for Human Occupancy; American Society of Heating, Refrigerating and Air-Conditioning Engineers, Inc.: Atlanta, GA, USA, 2004.

36. ISO 7730 Ergonomics of the Thermal Environment-Analytical Determination and Interpretation of Thermal Comfort Using Calculation of the PMV and PPD Indices and Local Thermal Comfort Criteria; International Organisation for Standarisation: Geneva, Switzerland, 2005.

37. EN 12464-1 Light and Lighting-Lighting of Work Places_Part 1: Indoor Work Places; European Commitee for Standardization (CEN): Brussels, Belgium, 2011.

38. EU GPP Criteria for Street Lighting \& Traffic Signals. Available online: http://ec.europa.eu/ environment/gpp/eu_gpp_criteria_en.htm (accessed on 16 November 2015).

39. EN 15242 Ventilation for Buildings_Calculation Methods for the Determination of Air Flow Rates in Buildings including Infiltration; European Commitee for Standardization (CEN): Brussels, Belgium, 2007.

(C) 2015 by the authors; licensee MDPI, Basel, Switzerland. This article is an open access article distributed under the terms and conditions of the Creative Commons Attribution license (http://creativecommons.org/licenses/by/4.0/). 